\title{
Analysis Of Difficulty Of Student's Geometry Problem Solving Based On Van Hiele's Thinking Theory With Macromedia Flash
}

\author{
Philips Pasca G Siagian \\ Universitas Negeri Medan, Jl. William Iskandar Ps. V, \\ Deli Serdang, Sumatera Utara 20371, Indonesia \\ Bornok Singa \\ Universitas Negeri Medan, Jl. William Iskandar Ps. V, \\ Deli Serdang, Sumatera Utara 20371, Indonesia \\ Mulyono \\ Universitas Negeri Medan, Jl. William Iskandar Ps. V, \\ Deli Serdang, Sumatera Utara 20371, Indonesia
}

\begin{abstract}
This study aims to describe the level of students' geometry thinking based on Van Hiele's thinking theory, the level of students' geometric problem solving abilities, and analyzing students' difficulties in solving geometric problems. This type of research is qualitative descriptive research. The researcher took six research subjects consisting of low, medium, and high level geometry problem solving abilities to be interviewed and analyzed the types of difficulties experienced. The results of this study indicate that there are 26 students reaching level 0 (visualization), 21 students reach level 1 (analysis), 13 students reach level 2 (informal deduction), 6 students reach level 3 (deduction) and no one can reach level 4 (rigor). Furthermore, there are 13 students who have a low level of problem solving ability, 7 students have a medium level of problem solving ability, and 6 students have a high level of problem solving ability. The difficulties experienced by the research subject are described in each problem.
\end{abstract}

Keywords: Difficulties, Problem Solving, Geometry, Van Hiele Thinking Theory, Macromedia Flash

\section{INTRODUCTION}

Geometry is one branch of mathematics that is taught at the secondary school level. According to Abdussakir (2010), geometry occupies a special position in the mathematics curriculum, because of the many concepts contained in it. From a psychological point of view, geometry is the presentation of abstractions from visual and spatial experiences, for example fields, patterns, measurements and mapping. Whereas from a mathematical point of view, geometry provides approaches for problem solving, for example images, diagrams, coordinate systems, vectors, and transformations.

One of the concepts in mathematics learning that must be mastered at the junior high school level is geometry. The importance of geometry material for junior high school students can be seen in the graduate competency standard for Junior High School which is stated in Permendiknas Number 23 of 2006 which states that every junior high school graduate must be able to understand geometry, elements and geometry, size and measurement, and do problem solving related to geometry material (Wardhani, 2008). 
In general, the purpose of geometry learning is for students to gain confidence about their mathematical abilities (skills), become good problem solvers, can communicate mathematically, and can reason mathematically. But there are still many students who have difficulties in solving geometry problems (Muhassanah, 2014). Geometry learning contributes to helping students develop visualization skills, critical thinking, intuition, perspective, problem solving, constructing conjectures, deductive reasoning, logical arguments and proofs.

The importance of geometry material can also be seen from the number of basic competencies that students must master while in junior high school. According to national education minister's regulations number 22 of 2006 concerning the content standards for Primary and Secondary Education Units, from 59 basic competencies in junior high school mathematics subjects, 24 of them are geometry material. This means that almost the material taught by the mathematics teacher is geometry. The large percentage of geometry material that is received should make students good problem solvers.

But the reality in the field is that many students experience difficulties in solving geometry problems. As stated by Adolphus (2011), the mathematical material that is considered difficult and feared by students in mathematics is geometry. This resulted in students being reluctant to learn geometry and in the end the goal of learning geometry to develop problem solving abilities could not be achieved.

The low mathematical problem solving abilities of students will affect students' geometry problem solving abilities and in general high school students have difficulty in learning geometry material (OECD, 2016). The students' mathematical problem solving skills are still very poorly demonstrated through the 2015 Survey Program for International Student Assessment (PISA) organized by the new Organization for Economic Co-operation and Development (OECD) released several years ago, showing the results that Indonesia ranks 62 out of 70 countries with a score of 403 . But the achievement of the score is still below its international average score of 500. Mathematical questions in the PISA study more measure reasoning, problem solving and argumentation than questions that measure the standard technical capabilities related with memory and mere calculation.

Many factors cause low problem solving abilities. According to Krismiati (2013) the low problem-solving ability caused by learning that has been done so far is still patterned with the provision of materials followed by giving examples and exercises. In addition, in problem solving, students only have a little knowledge about various problem solving strategies because they are rarely taught by the teacher. Then, the inappropriate teaching method in teaching is the cause of the low mathematical problem solving abilities (Darmana, Sedanayasa \& Antari, 2013).

Other contributing factors are the treatment given by the teacher (the model, method, and learning approach used by the teacher) tend to be the same for each student, even though students have different ways of learning and thinking. According to Mulyana (2003) the teaching of good geometry must be in accordance with the abilities of the child. The ability of children can be seen from the process of thinking and application of skills in problem solving geometry. The application of Van Hiele's theory is believed to be able to overcome the difficulties of students in solving geometric problems, because this learning theory explains the development of student thinking in learning geometry.

According to Van Hiele's theory, one will go through five levels of development of thinking in learning geometry. Each level in the theory of thinking Van Hiele shows the characteristics of 
students' thinking processes in learning geometry and their understanding in the context of geometry.

The five levels of Van Hiele's geometrical thinking are: a) Level 0 (Visualization), at this level students only pay attention to wake up visually without knowing the characteristics of the build; b) Level 1 (Analysis), at this level students begin to analyze geometric concepts. Students have been able to recognize and determine the characteristics of wake by analyzing the properties possessed by the build; c) Level 2 (Informal Deduction), at this level students can see the relationship between traits in one gemetri building; d) Level 3 (Deduction), at this level thinking student deduction has begun to develop and deduction reasoning as a way to construct geometric structures in axiomatic systems has been understood; and e) Level 4 (Rigor), at this level can understand the use of indirect evidence and evidence through counterpositivity, and can understand non-Euclidean systems (Burger \& Shaughnessy, 1986).

Some of the research that has been done proves that the application of Van Hiele's theory has a positive impact on learning geometry. By knowing the characteristics of students' geometry skills in solving geometry problems based on the level of thinking Van Hiele is expected the teacher is able to apply learning methods that are in accordance with the characteristics of each student and choose the right learning media.

However, the reality in the field shows that most teachers rely solely on images built up by static space in the book to explain geometric material to students. Building the space presented on a piece of paper will be very difficult for students to visualize. The problem that arises is that students have difficulty understanding the material because the explanation is still limited to the explanation of the concept through lectures on the board. For this reason, media is needed that can help students visualize waking up space.

The use of learning media is one of supporting the achievement of learning objectives for example in learning geometry. Abstract geometry can be easily studied which is presented in a concrete form in the form of a model, image or animation. This concrete form must be sought by the teacher so that the objectives of geometry learning can be achieved.

One of the learning media that can be used in geometry learning is the Macromedia Flash software. Macromedia flash is the right software for making visual offerings that can interpret various media, such as video, animation, images and sound. This software is quite reliable in making various kinds of interactive and interesting tutorial applications. The advantage of Macromedia Flash is that it attracts students to learn because the material is easier to understand. They can see the animation running alone by clicking the play button. So, what they imagine can be seen visually (Utama 2012). This allows students not to memorize more about abstract mathematical concepts that become real. Therefore, learning needs to be done through Van Hiele's thinking theory assisted by macromedia flash learning media to overcome students' difficulties in solving geometry problems.

\section{METHODS}

The type of research used in this research is qualitative descriptive research. This research was conducted in SMP Methodist 7 Medan, in the Academic Year 2018/2019. The subjects in this study were class VIII amounting to 26 students. The researcher determines the research subject by using purposive sample. In this study, were selected 2 students from the low, medium, and high geometry problem solving levels. So the subjects in this study were 6 students. 


\section{Data Collection Technique}

Data collection techniques in this study were tests of students' geometry problem solving abilities and transcripts of interview researchers with research subjects. Interviews were conducted on each subject of the study aimed to find out information relating to the steps to solving problems and difficulties experienced by students in solving problems. Then triangulation of data was done to compare the results of the geometry solving and transcript ability tests of interview researchers and research subjects.

The test instrument used in this study was to measure the problem solving abilities of students in mastering cube and beam material. The test of geometry problem solving ability consists of five problems. Each problem contains the characteristics of Van Hiele's level of thinking.

After the learning device and the test instrument are compiled, every problem is examined to verify the suitability of the material and language. Learning devices and test instruments were validated by three lecturers and two teachers of junior high school mathematics. The validity test in this study consisted of the validity test of the material expert learning device and the validity test of the material expert. In validating the items, the validator gives an opinion. For the validity of the item test there are three rating choices, namely V = Valid, VWR = Valid With Revision, and I = Invalid.

After the learning device is validated by experts, the results are presented in Table 1.

Table 1. Results of Learning Device Validation by Material Experts

\begin{tabular}{|c|l|c|c|}
\hline No. & \multicolumn{1}{|c|}{ Object Assessed } & $\begin{array}{c}\text { Validation } \\
\text { Average Value }\end{array}$ & $\begin{array}{c}\text { Level of } \\
\text { Validation }\end{array}$ \\
\hline 1 & Lesson Plan & 4,46 & Valid \\
\hline 2 & Student Worksheet & 4,35 & Valid \\
\hline
\end{tabular}

Based on the results of the learning device validation by the material experts that have been presented at Table 1, it can be concluded that the learning devices that have been compiled are classified as valid criteria.

Furthermore, after testing the geometry problem-solving ability validated by experts, the results are presented in Table 2.

Table 2. Results of Validation of Geometry Problem Solving Test

\begin{tabular}{|c|l|c|c|c|c|}
\hline \multirow{2}{*}{ No. } & \multicolumn{5}{|c|}{ Validator } \\
\cline { 2 - 6 } & L1 & L2 & L3 & T1 & T2 \\
\hline 1 & VWR & VWR & VWR & VWR & VWR \\
\hline 2 & VWR & VWR & VWR & VWR & VWR \\
\hline 3 & VWR & VWR & VWR & VWR & VWR \\
\hline 4 & VWR & VWR & VWR & VWR & VWR \\
\hline 5 & VWR & VWR & VWR & VWR & VWR \\
\hline
\end{tabular}

notes: $\mathrm{L}=$ Lecture, $\mathrm{T}=$ Teacher

Based on the results of the validation tests of geometry problem solving abilities by material experts that have been presented in Table 2, it can be concluded that the items are classified as valid with revisions. 


\section{Data Analysis Technique}

In this study, the data analysis technique used was the analysis of quantitative and qualitative data. Quantitative analysis was carried out to determine the distribution of the level of geometric thinking and the level of students' geometry problem solving ability. The level distribution of students' geometric thinking is obtained based on student achievement in Van Hiele's geometry level. While the level of geometry problem solving ability is categorized based on the scores obtained by students. Then qualitative analysis is carried out to describe the errors in the answer sheet of the research subject and the conclusions of the difficulties experienced by the research subjects obtained from the summary transcript of the interview.

The steps in analyzing data in this study are data reduction, data presentation, and conclusion. Data reduction in this study is the activity of selecting, focusing, extracting, and formulating all data obtained from the field. The activity carried out was to examine the results of the tests and classify the students' answers into the level of geometry problem solving abilities. Then make interview transcripts related to the mistakes made by the research subjects. The presentation of the data in this study is to analyze the results of the tests combined with the results of interviews with the subject of the study in the form of narrative text. Drawing conclusions in research is in the form of difficulties experienced by students from the summary transcript analysis interview researchers and research subjects.

\section{Distribution of Student Geometry Thinking Levels \\ RESULTS AND DISCUSSION}

Tests of geometry problem solving abilities are arranged based on indicators of Van Hiele's level of thinking and using polya problem solving steps.. This test was tested on 26 students then examined. From the results of the examination, students will be grouped into five stages of thinking level of Van Hiele. Grouping the level of thinking of Van Hiele is not referring to the scores obtained by students but based on student achievement in answering problems at that level. This geometry problem solving ability test is hierarchical so students must reach the lowest level first and then reach the next level. The level of geometry thinking of students is presented in Table 3.

Tabel 3. Student's Geometry Thinking Levels

\begin{tabular}{|c|l|c|}
\hline Level & $\begin{array}{l}\text { Many Students Based on Absent } \\
\text { Numbers }\end{array}$ & $\begin{array}{c}\text { The Number } \\
\text { of Students }\end{array}$ \\
\hline 0 & $\begin{array}{l}1,2,3,4,5,6,7,8,9,10,11,12,13,14,15, \\
16,17,18,19,20,21,22,23,24,25,26\end{array}$ & 26 \\
\hline 1 & $\begin{array}{l}1,2,3,5,6,7,8,9,10,11,12,13,15,16, \\
18,19,20,22,23,25,26\end{array}$ & 21 \\
\hline 2 & $1,2,3,5,6,7,9,11,13,18,20,23,26$ & 13 \\
\hline 3 & $2,3,13,20,23,26$ & 6 \\
\hline 4 & - & \\
\hline
\end{tabular}

In Table 3, the results of the grouping level of geometry thinking of students listed are based on the student sequence number. From the data in Table 3, there is a proportion of students' geometriy problem solving abilities at each level of thinking that are viewed from the level of Van Hiele' geometry thinking. Table 3 shows that there is a reduction in the number of students who can reach the lowest to the highest level of geometry thinking. So it can be concluded that the higher the level of thinking geometry, the fewer students can achieve it. 


\section{Level of Students' Geometry Problem Solving Abilities}

After the test is tested, scoring of the student worksheet is given. Scoring tests of students' geometry problem solving abilities are given based on scoring guidelines that have been prepared. Then the percentage level of students' geometry problem solving abilities is presented in the Table 4.

Table 4. Results of Students' Geometry Problem Solving Test

\begin{tabular}{|c|c|c|c|c|}
\hline No & Interval GPSAS & $\begin{array}{c}\text { The Number } \\
\text { of Students }\end{array}$ & Percentage & Level \\
\hline 1 & $0 \leq$ GPSAS $<65$ & 13 & $50 \%$ & Low \\
\hline 2 & $65 \leq$ GPSAS $<80$ & 7 & $26,92 \%$ & Medium \\
\hline 3 & $80 \leq$ GPSAS $<100$ & 6 & $23,08 \%$ & High \\
\hline
\end{tabular}

notes: GPSAS = Geometry Problem Solving Abilities Score

Viewed from Table 4, there were many students who had a moderate level of geometry problem solving ability, 13 students and many students who had a low level of geometry problem solving ability were 13 students. Because there are still many students who have a low level of problem solving ability in geometry, this shows that there are still many students who make mistakes in solving geometry problems. So it is necessary to explore the difficulties experienced by students who make mistakes in solving geometry problems.

\section{Taking Research Subjects}

The research subjects were selected based on the level of students' geometry problem solving abilities. Then two students were taken from each level of geometry problem solving ability to be used as the subject of the study.

To make it easier to describe the difficulties experienced by the research subjects, the six research subjects were given symbols S-1 through S-6. The selected research subjects are presented in Table 5.

Table 5. Selected Research Subjects

\begin{tabular}{|c|c|c|}
\hline No & Research Subjects & Level \\
\hline 1 & S-1 & Low \\
\hline 2 & S-2 & \multirow{2}{*}{ Medium } \\
\hline 3 & S-3 & Low \\
\hline 4 & S-4 & \multirow{2}{*}{ S-5 } \\
\hline 5 & S-6 & \\
\hline 6
\end{tabular}

The selected research subject worksheets were analyzed based on Van Hiele's level of thinking characteristics and Polya's problem solving steps. Furthermore, in-depth interviews were conducted on selected research subjects to gather information about the difficulties experienced in solving geometry problems. Interviews carried out on each problem that can be solved by the research subject. The transcript results of the interviewer's research and research subjects are summarized, then analyzed the characteristics of the difficulties experienced by the subject of the study. Based on a summary of the characteristics of difficulties, it is concluded that the difficulties experienced by the research subjects referred to in the pattern of geometry problem solving difficulties that have been compiled. 


\section{Analysis of Research Subject Difficulties}

Analysis of geometry problem solving difficulties for the subject of research is carried out on each problem or at each level of geometric thinking. These difficulties are obtained from the results of interviews of researchers with the subject of research referring to the answers given by the subject. The description of the difficulties experienced by the research subject is limited to one at each level of geometry problem solving abilities.

The results of the geometry solving ability test show that S-1 and S-2 have a low level of problem solving ability, and are only able to solve problems 1 . So the researcher will describe the difficulties experienced by S- 1 in solving each problem. Furthermore S-3 and S-4 have a medium level of problem solving ability, which is only able to solve problem 1, problem 2 , and problem 3. So the researcher will describe the difficulties experienced by S-3 in solving each problem. And finally, S-5 and S-6 have a high level of problem solving ability, which is able to solve problem 1 , problem 2 , problem 3 , and problem 4 . Then the researcher will describe the difficulties experienced by S-5 in solving each problem.

a. Analysis of Difficulties Problem 1

S-1 Answer Results on Problem 1

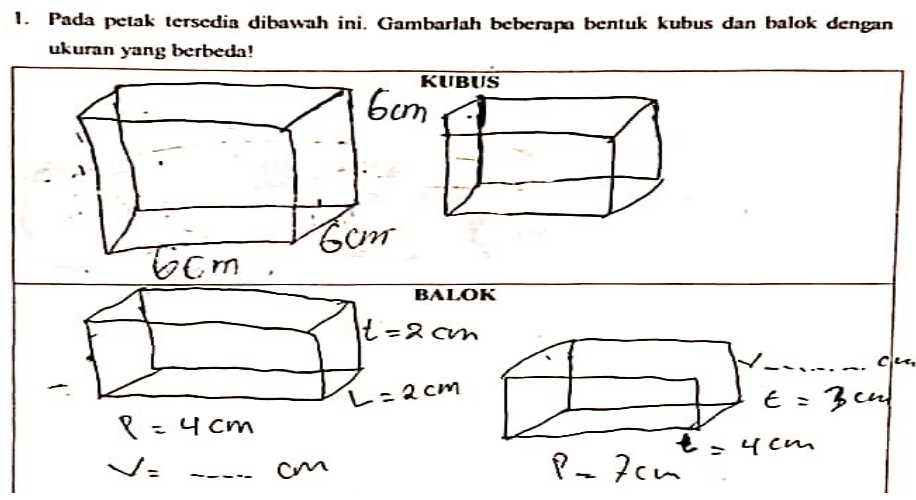

Figure 1. S-1 Answer Results on Problem 1

Based on Figure 1, it can be seen that S-1 can describe one cube and two beams with sizes that match the characteristics of cubes and beams.

\section{S-1 Interview Results on Problem 1}

The interview transcript results reveal that S- 1 does not know the definition of cube or beam, it can be said that he does not know the characteristics of the beam or cube.

'This is a characteristic of the difficulty of the concept. Then it can be concluded that S-1 had difficulty in the concept of problem solving $1 "$. 


\section{S-3 Answer Results on Problem 1}

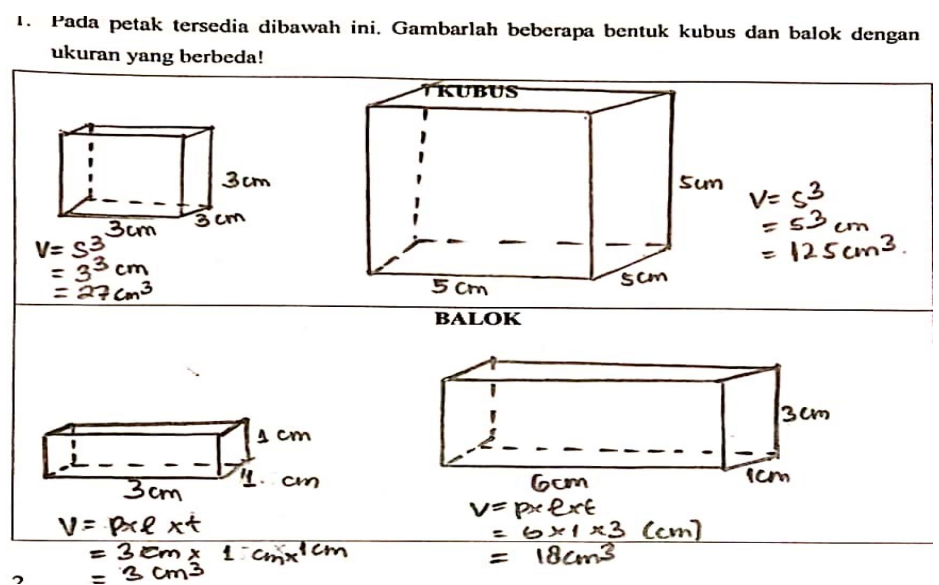

Figure 2. S-3 Answer Results on Problem 1

Based on Figure 2, it can be seen that S-3 can describe two cubes and two beams with sizes that match the characteristics of cubes and beams. And also S-3 can calculate the volume of cubes and beams correctly.

\section{S-3 Interview Results on Problem 1}

The interview transcript results revealed that when S-3 was asked why you made the size of the ribs on the side of the cube with all the different blocks, he could answer that each rib on the side of the cube had the same length if it was different. This shows that S-3 knows the characteristics of cubes and beams so that they can draw cubes and blocks correctly.

'Through the summary above, the S-3 has no difficulty in drawing two cubes and two blocks. This shows that the S-3 has no difficulty in solving problem 1".

\section{S-5 Answer Results on Problem 1}

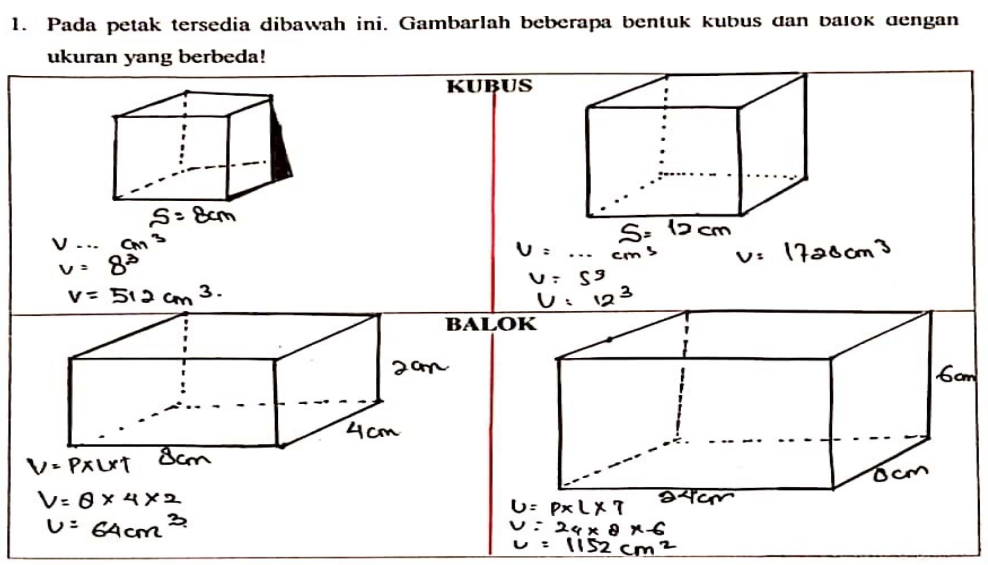

Figure 3. S-5 Answer Results on Problem 1

Based on Figure 3, it can be seen that $S-5$ can describe two cubes and two beams with sizes that match the characteristics of cubes and beams. And also S-5 can calculate the volume of cubes and beams correctly.

\section{S-5 Interview Results on Problem 1}

The interview transcript results revealed that when S-5 was asked why you made only one rib on the side of the cube but on a different beam, he could answer that each rib on the side of the cube had the same length if it was different then called a beam. This shows that the S-5 
research subject knows the characteristics of cubes and beams so that they can draw cubes and blocks correctly.

'Through the summary above, the S-5 research subjects did not have difficulty drawing two cubes and two blocks. This shows that the S-5 research subject had no difficulty in solving problem 1".

b. Analysis of Difficulties Problem 2

S-1 Answer Results on Problem 2

\begin{tabular}{|c|c|}
\hline KUBUS & BALOK \\
\hline $\begin{array}{l}\text { Rusuk sejajar: } \\
\text { Tu,PA, } T P_{1} \cup Q_{1} T W, S T \\
W S, V R, T W I P S, \cup U, Q R\end{array}$ & $\begin{array}{l}\text { Rusuk scjajar: } \\
\sigma f_{1} A B, E q, F B, H g, D C, H D, E C \\
E H, A D, F g, B C\end{array}$ \\
\hline $\begin{array}{l}\text { Sisi sejajar: } \\
\text { TUPQ, WVST, TUPS,UNQ } \\
\text { KWUU, PQRS }\end{array}$ & $\begin{array}{l}\text { Sisi sejajar: } \\
E F, B A, H g C D, E H g F, \\
A D C B, E H D A, F Q C B\end{array}$ \\
\hline
\end{tabular}

Figure 4. S-1 Answer Results on Problem 2

Based on Figure 4, it can be seen that S-1 has not been able to determine the pair of ribs and sides that are parallel to the cube or beam. S-1 only mentions each rib and side on the cube or on the beam.

\section{S-1 Interview Results on Problem 2}

The interview transcript results revealed that when S-1 was told to mention a pair of parallel ribs, he only mentioned the ribs in the PQRSTUV cube. In addition, when asked for the definition of a parallel pair of ribs, the $S 1$ cannot answer it. The same is true when $S-1$ is told to mention parallel pairs, he only mentions the sides in the PQRSTUV cube. This case shows that S-1 research subjects do not neglect the properties of cubes or beams.

'Through the summary above, the difficulties experienced by S-1 are the characteristics of the difficulties of the concept. Then it can be concluded that S-1 has difficulty in the concept of problem solving 2 ".

S-3 Answer Results on Problem 2

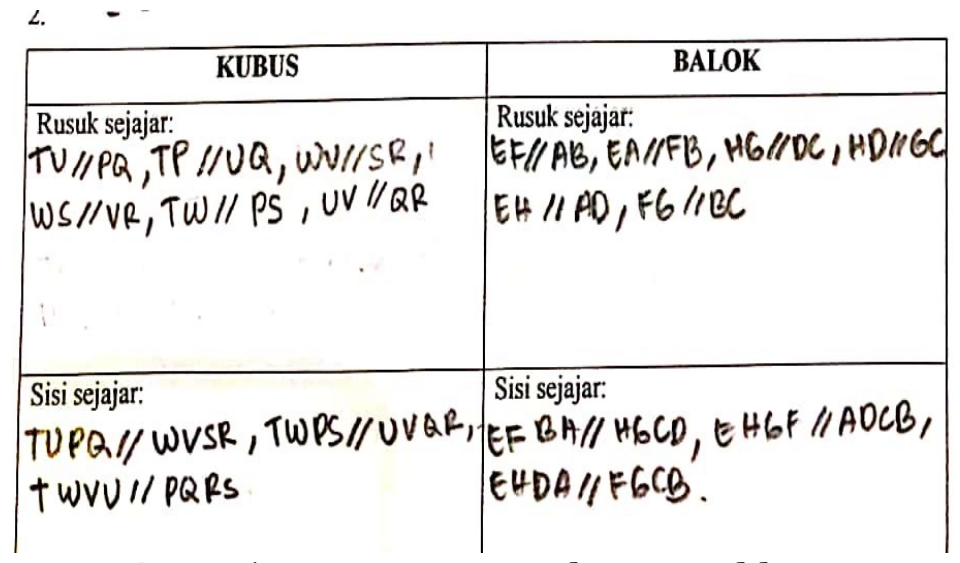

Figure 5. S-3 Answer Results on Problem 2 
Based on Figure 5, it can be seen that S-3 can determine the pair of ribs and sides parallel to the cube or beam. But the $S-3$ has not been able to determine all pairs of ribs on the cube or beam.

\section{S-3 Interview Results on Problem 2}

The interview transcript results revealed that when the S-3 was told to mention a pair of parallel ribs, he could mention several pairs of parallel ribs. But when asked how the relationship between TU and WV ribs, he was hesitant in answering. Even though the two ribs are parallel rib pairs. The $S-3$ does not know the conditions of parallel rib pairs. This case shows that S-3 does not recognize the characteristics of the cube.

'Through the summary above, the difficulties experienced by the S-3 are difficulties in recognizing the characteristics of the cube. This is a characteristic of the difficulty of the concept. Then it can be concluded that S-3 has difficulty in the concept of problem solving 2 “.

\section{S-5 Answer Results on Problem 2}

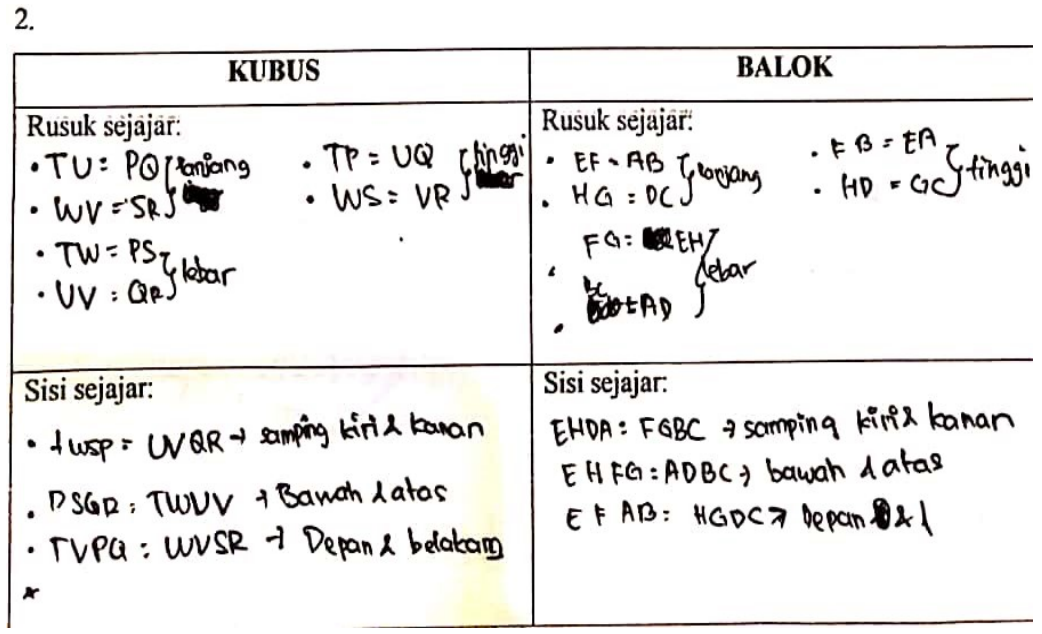

Figure 6. S-5 Answer Results on Problem 2

Based on Figure 6, it can be seen that S-5 can determine the pair of ribs based on length, width, and height on the cube or beam. And it can also specify parallel side pairs. But the S-5 has not been able to determine all pairs of ribs parallel to the cube or beam.

\section{S-5 Interview Results on Problem 2}

The interview transcript results revealed that when S-5 was told to mention a pair of parallel ribs, he could mention several pairs of ribs parallel. But when asked how the relationship between the ribs of TU and VQ, he was hesitant in answering. Even though the two ribs are parallel rib pairs. Then S-5 mentions the pair of ribs on the cube based on their side pairs. S-5 does not know the conditions of parallel rib pairs. This case shows that S-5 does not recognize the characteristics of the cube.

'Through the summary above, the difficulties experienced by the S-5 are difficulties in recognizing the characteristics of the cube. This is a characteristic of the difficulty of the concept. Then it can be concluded that S-5 has difficulty in the concept of problem solving 2 ".

c. Analysis of Difficulties Problem 3

S-3 Answer Results on Problem 3 


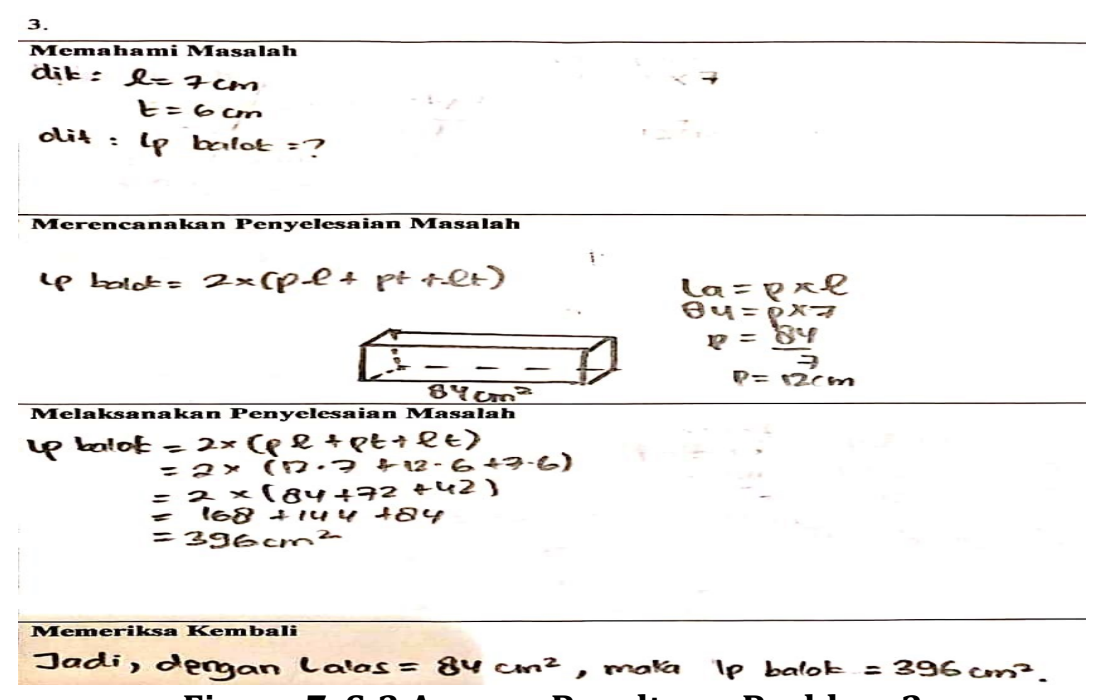

Figure 7. S-3 Answer Results on Problem 3

Based on Figure 7, it can be seen that S-3 can solve problem 3 by using polya problem solving steps.

\section{S-3 Interview Results on Problem 3}

The interview transcript results revealed that when $\mathrm{S}-3$ was asked which part was said to be the base of the beam, he could answer that the base of the beam was the bottom side of the beam. Then the S-3 knows the problem solving plan and can do problem solving and can draw conclusions.

'Through the summary above, the S-3 did not have difficulty in calculating the surface area of the beam. This shows that S-3 has no difficulty in solving problems 3 ".

S-5 Answer Results on Problem 3

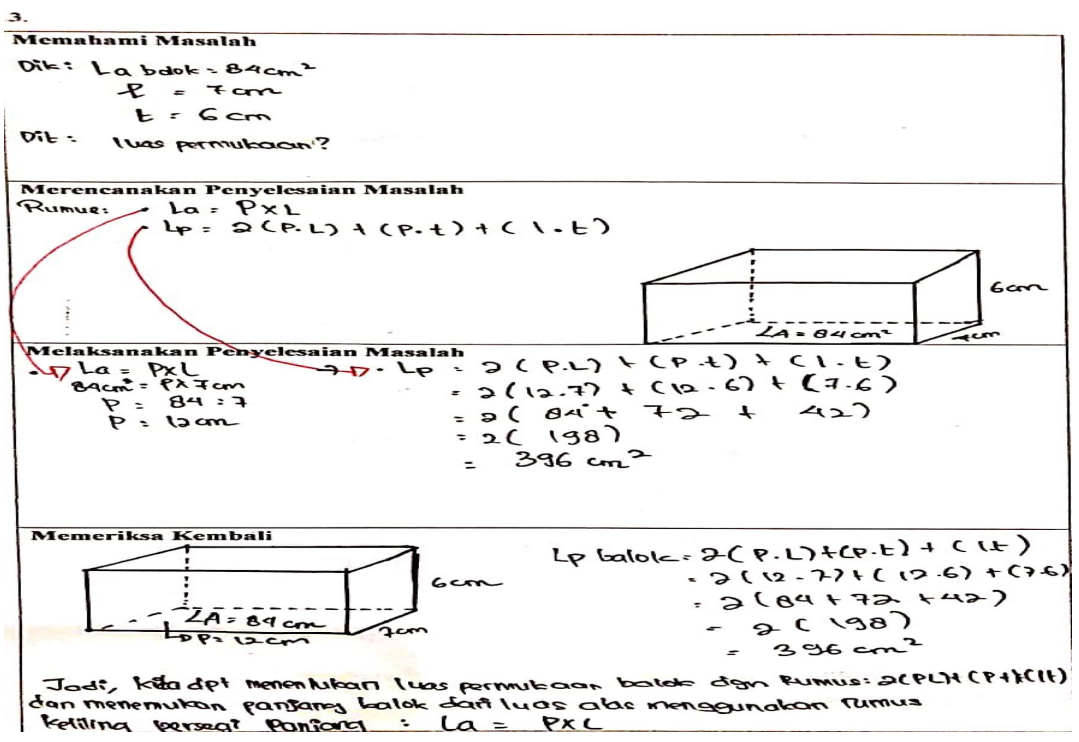

Figure 8. S-5 Answer Results on Problem 3

Based on Figure 8, it can be seen that S-5 can solve problem 3 by using polya problem solving steps.

S-5 Interview Results on Problem 3

The interview transcript results revealed that when the $S-5$ was asked which part was said to be the base of the beam, he could answer that the base of the beam was the bottom side of the 
beam. Then the S-5 knows the problem solving plan and can do problem solving. Then in the step of re-checking the S-5 can describe the complete beam with the length, width, height and area of the base of the beam and draw conclusions from the overall steps of problem solving. 'Through the summary above, the S-5 did not have difficulty in calculating the surface area of the beam. This shows that S-5 has no difficulty in solving problem 3".

d. Analysis of Difficulties Problem 4

S-5 Answer Results on Problem 4

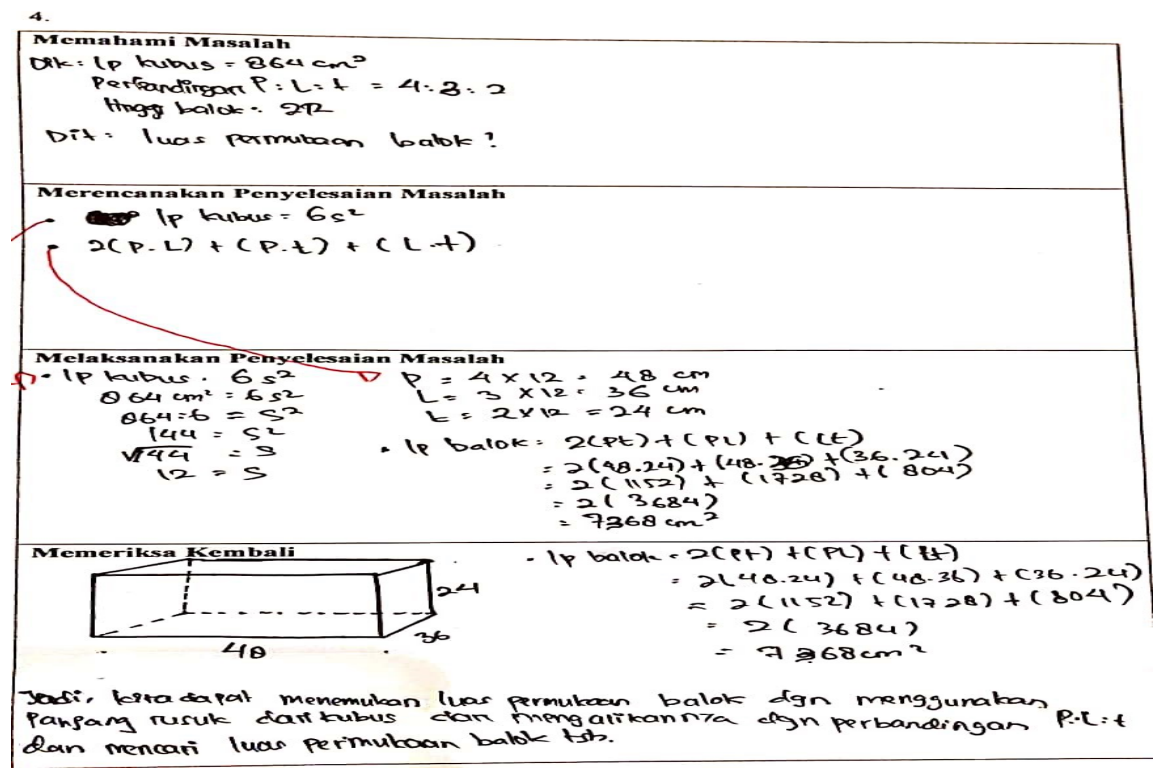

Figure 9. S-5 Answer Results on Problem 4

Based on Figure 9, it can be seen that $\mathrm{S}-5$ can solve problem 4 by using polya the problem solving steps.

S-5 Interview Results on Problem 4

The results of the interview transcript revealed that the S-5 can write what is known and asked on problem 4 into mathematical symbols. Then S-5 can see the relationship between the properties of the cube and the beam. So the $S-5$ can do problem solving steps. But the S-5 made a mistake in the problem solving step. S-5 is wrong in calculating the surface area of the beam. Through the summary above, the difficulties experienced by the S-5 are difficulties in performing problem solving procedures. This is a characteristic of skill difficulties. Then it can be concluded that S-5 has difficulty in problem solving skills 4".

\section{DISCUSSION}

After the test results are presented, the findings in this study are obtained, that there is no student can solve the problem 5 at each step of the problem solving problem. So that none of the students is at level 4 (rigor).

The next finding is that there are 6 students (23.08\%) out of 26 students who take the test of geometry problem solving ability at level 3 (informal deduction). The percentage of students who can reach this level of informal deduction is classified as many. If referring to relevant research, from several research results it is shown that there are still many students who have not been able to reach the level of informal deduction.

Based on the results of the research that has been obtained, there are several findings of field research, namely the difficulty of the geometry problem solving ability of the research subject. 
Research findings related to the difficulties experienced by research subjects in the geometry problem solving at each level of geometry problem solving ability are presented in Table 6 .

Table 6. Difficulties Geometry Problem Solving in Research Subjects

\begin{tabular}{|c|c|l|l|}
\hline Level & $\begin{array}{l}\text { Research } \\
\text { Subjects }\end{array}$ & Problems & $\begin{array}{l}\text { Difficulties Geometry } \\
\text { Problem Solving }\end{array}$ \\
\hline \multirow{2}{*}{ Low } & \multirow{2}{*}{ S-1 } & Problem 1 & Difficulty in concept \\
\cline { 3 - 4 } & \multirow{3}{*}{ Medium } & Problem 2 & Difficulty in concept \\
\hline \multirow{3}{*}{ S-3 } & Problem 1 & No Difficulty \\
\cline { 3 - 4 } & & Problem 2 & Difficulty in concept \\
\cline { 3 - 4 } & \multirow{3}{*}{ High } & Problem 3 & No Difficulty \\
\hline \multirow{3}{*}{ S-5 } & Problem 1 & No Difficulty \\
\cline { 3 - 4 } & & Problem 2 & Difficulty in concept \\
\cline { 3 - 4 } & & Problem 3 & No Difficulty \\
\cline { 3 - 4 } & & Problem 4 & Difficulty in skills \\
\hline
\end{tabular}

\section{CONCLUSION}

Based on the description of the results of the research, the following conclusions are obtained:

1. There are 26 people able to reach level 0 (visualization) or can draw cubes and beams according to the characteristics of; 21 people able to reach level 1 (analysis) or can mention the pair of ribs and parallel sides; 13 people able to reach level 2 (informal deduction) or can solve a problem using beam properties in determining the surface area of the beam;

6 people able to reach level 3 (deduction) or can solve problems by linking concepts to cubes and beams in determining the surface area of the beam.

2. The level of geometry problem solving ability of students from 26 students, namely: 13 $(50 \%)$ students were at low level, 7 (26.92\%) students were at medium level, 6 $(23.08 \%)$ students were at high level.

3. The geometry problem solving difficulties of the research subjects are $\mathrm{S}-1$ has a difficult concept on problem 1 and problem 2 . S-3 has difficulty skills in problem 1 , has difficulty in concept on problem 2, and has difficulty in principle on problem 3. S-5 has no difficulty in problem 1 , has difficulty concept on problem 2 , has difficulty skills in problem 3 and has difficulty skills in problem 4.

\section{References}

Abdussakir. 2010. Pembelajaran Geometri Sesuai Teori van Hiele. El-Hikmah Jurnal Kependidikan dan Keagamaan, 7(2), ISSN 1693-1499.

Adolphus, T. 2011. Problems of Teaching and Learning of Geometry in Secondary Schools in Rivers State Nigeria. International Journal of Emerging Sciences. 1 (2): 143-152.

Burger, W.F, Shaughnessy, J. M. 1986. Characterizing the van Hiele Levels of Development in Geometry. Journal for Research in Mathematics Education. 17(I):31-48.

Darmana, I. K. R., Sedanayasa, G., Antari, N. N. M. 2013. Pengaruh Model Problem-Based Instruction Terhadap Kemampuan Pemecahan Masalah Dalam Pembelajaran matematika. Mimbar PGSD, 1.

Krismiati, A. 2013. Penerapan Pembelajaran Dengan Pendidikan Matematika Realistik (PMR) Secara Berkelompok Untuk Meningkatkan Kemampuan Pemecahan Masalah Matematis Siswa Di Kelas X SMA. Jurnal Infinity, 2(2), 123135

Mulyana, E. 2003. Masalah Ketidaktepatan Istilah Dan Simbol Dalam Geometri SLTP Kelas 1. Dalam file.upi.edu/...ENDANG MULYANA/Psikologi_geometri. Diakses 1 Maret 2013.

Muhassanah, Sujadi, Riyadi. 2014. Analisis Keterampilan Geometri Siswa Dalam Memecahkan Masalah Geometri Berdasarkan Tingkat Berpikir Van Hiele. Jurnal Elektronik Pembelajaran Matematika. Vol.2, No.1, hal 54 - 66, Maret. 
OECD. 2016. PISA 2015 Assesment and Analytical Framework. Paris: OECD Publisher.

Purba, E. P. Sinaga, B. Mukhtar. \& Surya, E. 2017. Analysis of the Difficulties of the Mathematical Creative Thinking Process in the Application of Problem Based Learning Model. Advances in Social Science, Education and Humanities Research,.volume 104, pp: 265-268.

Sinaga, B. 2007. Pengembangan Model Pembelajaran Matematika Berdsarkan Masalah Berbasis Budaya Batak (PBMB3). Disertasi. Tidak Dipublikasikan. Surabaya: PPs Universitas Negeri Surabaya

Wardhani, S. 2008. Analisis SI dan SKL Mata Pelajaran Matematika SMP/MTs untuk Optimalisasi Tujuan Mata Pelajaran Matematika. Yogyakarta: Pusat Pengembangan dan Pemberdayaan Pendidik dan Tenaga Kependidikan Matematika. 